\title{
Application of additives with gasoline fuel: A review
}

\author{
Mayur Jadhav ${ }^{1, *}$, Swati Jadhav ${ }^{1}$, and Supriya Chavan ${ }^{2}$ \\ ${ }^{1}$ Government College of Engineering, Karad, Maharashtra, India \\ ${ }^{2}$ Indian Biodiesel Corporation, Baramati, Maharashtra, India.
}

\begin{abstract}
Alternative fuels have become very important nowadays and proving their importance in both positive ignition engines and compression ignition engines, so as to reduce the consumption of gasoline and diesel respectively. Also, blending of these alternative fuels (additives) into gasoline has been proved important in improving various performance parameters and reducing emission parameters. Various studies have been carried out in the field of using additives in gasoline to see the effects on performance parameters like Brake power, Brake thermal efficiency, Volumetric efficiency and brake specific fuel consumption. Also, this study emphasizes reducing the emissions to the ambient. The aim of this review is to compare and study various additives which can be blended with gasoline and study their effect on performance and emission characteristics of Spark ignition engines.
\end{abstract}

\section{Introduction}

Fossil fuels serve as one of the primary energy sources for the world today. World energy demand is increasing day by day due to rapidly increasing population. Prices of fossil fuels are increasing due to increasing demand which is impacting the economy of nations where fossil fuel production is not significant. Fossil fuels are hazardous for the environment and are causing the effects like acid rain, ozone layer depletion and the greenhouse effect. Therefore, worldwide research in the field of alternative fuel sources for engines is carried out.

Gasoline consists of C-4 to C-12 hydrocarbons and it is a mixture of alkanes, alkenes and cycloalkanes. Generally used chemical formula for gasoline is $\mathrm{C}_{6.97} \mathrm{H}_{14}$.

Over the years, rules and regulations regarding the emission standards are changing and demand reduction in emissions from automobiles. From April 2020 BS-VI (Bharat stage VI) emission standards will be implemented in India which require reduction in $\mathrm{NO}_{\mathrm{x}}$ and $\mathrm{CO}$ emissions as compared to BS-IV (Bharat Stage IV) standards. Hydrocarbon (HC) emission limit has been kept the same in BS-IV as well as BS-VI standards. $\mathrm{NO}_{\mathrm{x}}$ emission limits are reduced by $25 \%$ for light duty vehicles (M1, M2, N1 Class I, N1 Class II, N1 Class III, N2) as per BS VI standards as compared to BS IV standards whereas $\mathrm{CO}$ emission limits are kept unchanged. For three wheelers $\mathrm{NO}_{\mathrm{x}}$ emission limits are kept unchanged and $\mathrm{CO}$ emission limit is reduced by $53 \%$ in BS VI as compared to BS IV. For two wheelers, $\mathrm{NO}_{\mathrm{x}}$ emissions are reduced by $85 \%$ for class 1 and $2-1$, $82 \%$ for class $2-2$ and $70 \%$ for class $3-1$, class $3-2$. CO emission limits are reduced by $29 \%$ for class 1 and $2-1$,
$49 \%$ for class $2-2$ and by $49 \%$ for class $3-1,3-2$. With the help of additives it is observed that there is improvement in performance and reduction in emissions. Hence we can comply to BS VI emission standards with the use of various additives.

There are various additives that are added to gasoline for boosting the performance and reducing emissions. Additives are mainly characterised into two categories Eco-friendly additives (bio-additives) and Chemical based additives. Bio-additives mainly consist of Ethanol, Turmeric leaf oil and algae oil. Whereas Chemical based additives are mainly categorised as follows:

a) Oxygenates: Propyl alcohol, Butyl alcohol, Isopropyl alcohol, gasoline grade t-butyl alcohol.

b) Ethers: Methyl tertiary-butyl ether, Tertiary-amyl methyl ether, Tertiary-hexyl methyl ether, Ethyl tertiary butyl ether, Tertiary-amyl ethyl ether.

c) Antiknock agents: Dimethyl methyl phosphate, Toluene, Isooctane, Triptane, etc.

d) Nanoparticles: $\mathrm{Fe}_{2} \mathrm{O}_{3}, \mathrm{TiO}_{2}$, etc.

e) Fuel additives in general: Ethers are used for running the engine in difficult to start engines. Nitro-methane is used for high performance in racing.

\section{Discussions}

Schematic of the experimental setup used by various researchers for performance, combustion and emission characteristics evaluation of fuel blends for an SI engine is shown in figure. 1. Experimental setup consists of a variable compression ratio SI engine fuelled with blends of gasoline and other additives. Five gas analyzer is used for measuring exhaust gases like $\mathrm{CO}_{2}, \mathrm{CO}, \mathrm{NO}_{\mathrm{x}}$ and $\mathrm{HC}$.

*Corresponding author: jadhavmayur455@gmail.com 


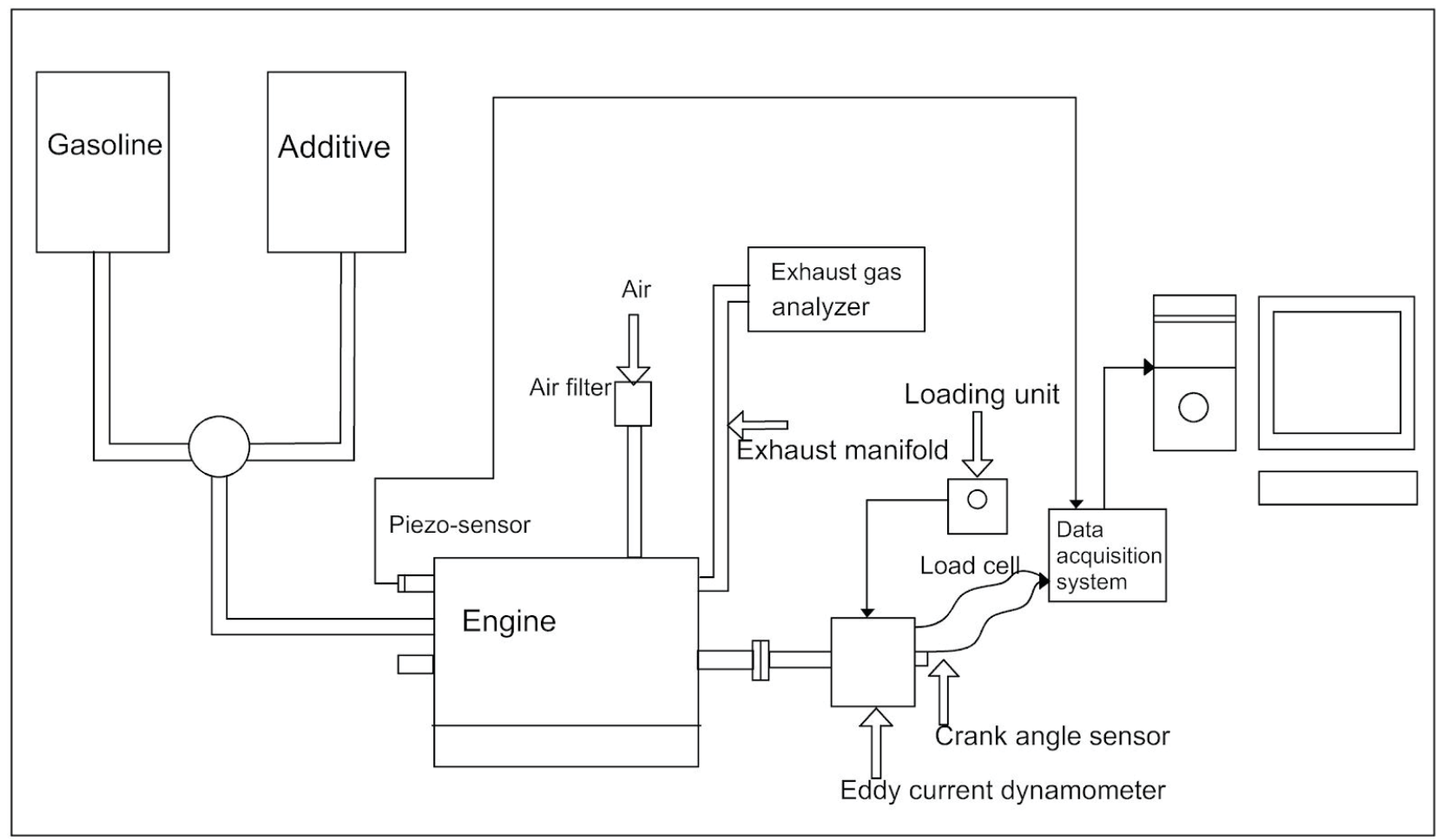

Figure. 1. Experimental schematic for performance, combustion and emission investigations on SI engine setup

\subsection{Literature review}

There are various researches carried out related to additives in gasoline. Brief overview of previous research along with different additives is given below:

Manish Saraswat and Nathi Ram Chauhan [1] investigated the use of butanol and algae oil blends. Compression ratio, blending percentage and load were varied and performance, emission parameters are determined. The studies indicated enhancement in power, torque and $\mathrm{HC}, \mathrm{CO}, \mathrm{NO}$ emissions were reduced with the use of butanol as additive. On the contrary, upsurge in nitrous oxide, carbon monoxide could be seen. For algae oil Brake specific fuel consumption, nitrous oxides and carbon monoxide emissions are scaled up whereas brake thermal efficiency is reduced.

M. Mourad and K. Mahmoud [2] investigated spark ignition engine performance and emission with ethanol/ butanol-gasoline mixtures. Gasoline is blended with butanol and ethanol in the blending percentage of $2 \%$, $5 \%, 10 \%, 15 \%$ and $20 \%$. Performance and pollutant emissions were measured at varying engine speeds at low loads applied to the engine. The results show that mitigation in exhaust gases were measured at variable engine speeds at low loading. The results show that there was a mitigation of exhaust gases from engine for Carbon monoxide and Hydrocarbons. Also there was a slight scale down in engine power which was $11 \%$ lower than neat gasoline. Also scale down in specific fuel consumption was recorded.
Ashraf Elfasakhany [3] investigated emission and performance of SI engines using ternary bio-ethanol, iso-butanol and gasoline blends. It was observed that ternary blends were responsible for reduction in emissions of $\mathrm{UHC}$ and $\mathrm{CO}$ while also mitigating performance compared to pure gasoline fuel. However by increasing the percentage of additives ( $>10 \%)$ engine performance shows considerable improvement in performance as compared to neat gasoline.

Mustafa Koç et al. [4] studied the effects of ethanol blends (E0, E50, E85) in unleaded gasoline at different compression ratios. The results indicated that ethanol blended with gasoline increases performance parameters such as engine torque, power and increases fuel consumption and reduces Carbon monoxide, nitrous oxides and hydrocarbons emissions. It was also found that if ethanol blended with gasoline then higher compression ratio without knock can be achieved.

Ashraf Elfasakhany [5] investigated performance and exhaust emissions from SI engine operated with ethanol-gasoline, methanol-gasoline and methanol-ethanol-gasoline blend $(3 \%, 7 \%$ and $10 \%$ each additive). Results show that when SI engine is operated with ethanol-methanol-gasoline blends then $\mathrm{CO}$ and UHC emissions were considerably reduced in comparison to base fuel. Methanol-gasoline blends recorded lowest $\mathrm{CO}$, UHC emissions whereas ethanol-gasoline blends exhibit moderate $\mathrm{CO}$ and UHC emissions. Highest volumetric efficiency and torque were recorded in case of ethanol-methanol blends 
whereas highest power output was recorded with ethanol-gasoline blends.

Mehmet Ilhan Ilhak et al. [6] studied engine performance, emission and combustion analyzes in SI engine fuelled by gasoline-acetylene blends. The testings were performed at $1500 \mathrm{rpm}$ engine speed and variable loads. To prevent knocking phenomena, the addition of acetylene to gasoline reduced brake thermal efficiency at rich stoichiometric condition and increased $\mathrm{CO}$ emissions whereas brake thermal efficiency was increased by adding acetylene to lean mixtures and decreased $\mathrm{CO}$ emissions. Also addition of acetylene increased combustion limits, reduced UHC emission and increased $\mathrm{NO}_{\mathrm{x}}$ emissions.

$\mathrm{Yu}$ Li et al. [7] studied combustion, emission and performance characteristics of MPFI SI engine fuelled with methyl alcohol, ethyl alcohol and butyl alcohol-gasoline blends under various blending percentage and engine loading conditions. The combustion phasing was improved using alcohol due to higher burning velocity, which subsequently reduced brake thermal efficiency. ethyl alcohol and methyl alcohol blends produced lowest UHC and $\mathrm{NO}_{\mathrm{x}}$ emissions.

Hazim Sharudin et al. [8] investigated the effects of iso-butanol mixing on SI engine operated with methanol-gasoline blends. methanol blend (5\%) was blended with iso-butanol additive for $5 \%, 10 \%, 15 \%$. Experiments were conducted at $100 \%$ load conditions with speed ranging between $1000-2500 \mathrm{rpm}$. The results show that $15 \%$ of iso-butanol in methanol-gasoline (M5) blend indicated scaling up in brake power, brake thermal efficiency and exhaust gas temperature as compared to other blends. In terms of engine emissions, above mentioned blends gave significant mitigation in carbon monoxide and hydrocarbons emissions as compared to neat gasoline.

I Gravlos et al. [9] studied emission parameters of SI engine operating on different alcohols blended with gasoline fuel. The alcohol component in the blends consisted of different alcohols like methyl alcohol, ethyl alcohol, propyl alcohol, butyl alcohol and pentyl alcohol. The parameters under test were engine speed, $\mathrm{CO}, \mathrm{CO}_{2}$, $\mathrm{NO}$ and $\mathrm{HC}$ emissions. During variable load tests, it was observed that $\mathrm{CO}$ and $\mathrm{HC}$ levels in engine emissions were scaled down with the use of alcohol-gasoline blends. NO emissions were higher as compared to base fuel.

Eran Alptekin and Mustafa Canakci [10] studied that performance and emission parameters of solketal-gasoline fuel blend in SI engines. Octane number, brake specific fuel consumption were increased as well as $\mathrm{CO}_{2}$ and $\mathrm{NO}_{\mathrm{x}}$ emissions were increased with the use of solketal blends as compared to neat gasoline. Hence, it was concluded that solketal can be used to improve octane number and as an oxygen providing fuel.

Mohsen Ghazikhani et al. [11] experimentally studied exhaust emitted and performance characteristics of a 2-stroke spark ignition engine fuelled with gasoline blended with ethanol. In this study performance characteristics such as delivery ratio, efficiency of trapping and scavenging efficiency were studied. Also, emissions of carbon monoxide, carbon dioxide and nitrous oxides and hydrocarbons were under consideration. In this experiment, gasoline was blended with ethanol in three different percentages of $5 \%$ to $15 \%$. Results were recorded for speed range of $2500 \mathrm{rpm}$ to $4500 \mathrm{rpm}$. Due to vaporization of ethanol scavenging efficiency enhanced along with delivery ratio. Also, for $5 \%$ ethanol in gasoline brake specific fuel consumption decreased even though ethanol has lower calorific value. Carbon monoxide emissions reduced by $71 \%$ for $15 \%$ ethanol blended gasoline sample. Hydrocarbon emissions decreased by $6 \%$ for $5 \%$ ethanol, $12 \%$ for $10 \%$ ethanol and around $18 \%$ for $15 \%$ ethanol. For $15 \%$ ethanol blended gasoline sample highest $\mathrm{NO}_{\mathrm{x}}$ reduction of $80 \%$ is observed and around $38 \%$ reduction in $\mathrm{NO}_{\mathrm{x}}$ for all other samples is observed.

Huseyin Serdar Yucesu et al [12] studied the effect of ethanol in gasoline fuel on operating performance and exhaust with different operating compression ratio. Blending percentages of $10 \%, 20 \%, 40 \%, 60 \%$ were used and the results were compared with neat gasoline. Experiments were performed with six different compression ratios of $8: 1,9: 1,10: 1,11: 1,12: 1$ and 13:1. It was observed that as the compression ratio increased, torque increased and with increase of blending percentage, torque is enhanced slightly for particular compression ratio. In the case of exhaust emissions, fuels containing $40 \%$ and $60 \%$ ethanol had a large effect on the emissions. The maximum reduction was obtained with $40 \%$ and $60 \%$ ethanol blend at $2000 \mathrm{rpm}$ speed. Average reduction of $\mathrm{CO}$ emissions were close to $11 \%$ for both $40 \%$ and $60 \%$ blends. Also hydrocarbons decreased was also observed which was comparatively higher than carbon monoxide.

Rinu Thomas et al. [13] experimentally studied the effect of varying compression ratio on emission and performance parameters of spark ignition engine operated with gasoline and n-butanol blends at different loading conditions. Parameters under consideration were brake thermal efficiency, exhaust gas temperature, emitted pollutants. Experiments were conducted at compression ratios of $7,8.5$ and 10 . The fuels used in study are pure gasoline and $20 \%$ n-butanol blended in gasoline. It was observed that thermal efficiency was improved at higher compression ratios. Combustion efficiency improves at higher temperature and pressure obtained at higher compression ratios. It was noticed that comparatively better results for brake thermal efficiency were obtained for $20 \%$ blend of n-butanol than neat gasoline. It was concluded that fuels having comparatively good anti-knocking properties will enhance brake thermal efficiency at higher compression ratio. As compression ratio is increased, reduced exhaust gas temperatures were recorded. This can be related to better conversion of heat energy to useful work. Higher in-cylinder temperature, pressure and 
stoichiometrically rich mixtures at maximum load resulted in enhanced exhaust gas temperature. It was observed that supply of stoichiometrically rich mixture at higher load results in incomplete combustion of fuel. This increases hydrocarbon and carbon monoxide emissions. The use of $20 \%$ blend reduces carbon monoxide emission at higher compression ratio and higher load. $\mathrm{NO}_{\mathrm{x}}$ emission is observed to be increased but that can be tackled by effective use of exhaust gas recirculation.

M. Bahattin Celik et al. [14] studied the effect of methanol fuel on single cylinder SI engine for variable compression ratios. In this experiment, methanol was used as as fuel at high compression ratio to enhance the performance and decrease the emissions. Knocking was observed at a compression ratio of 8 for gasoline while it was not observed for methanol fuel. The knock was determined from cylinder pressure-time curves. It was found that carbon monoxide, carbon dioxide and $\mathrm{NO}_{\mathrm{x}}$ emissions were reduced significantly with very less changes in brake power at $\mathrm{CR}=6: 1$. With increase in $\mathrm{CR}$ from 6:1 to $10: 1$ with methanol as a fuel, engine brake power and thermal efficiency increased. Also exhaust emissions were reduced with an increase in compression ratio.

Zhi Tian et al. [15] studied the various parameters in turbocharged direct injection spark ignition engine. Blending percentage of $10 \%$ and $20 \%$ each was used for methanol, ethanol and butanol. Neat gasoline was also tested simultaneously. It was observed that as the rpm was increased, there was an increase in torque for all the samples. It was observed that alcohol as an additive in gasoline increases brake torque as well as heat release rate. Highest increase in brake torque and heat release rate was observed for $20 \%$ methanol blend followed by $20 \%$ ethanol blend respectively. It was also found that adding alcohol increases thermal efficiency of the engine but it also results in increase in fuel consumption. $20 \%$ methanol has the highest thermal efficiency and fuel consumption. Also, decrease in carbon monoxide and carbon dioxide emissions is observed with the addition of alcohol.

Changwei Ji et al. [16] investigated performance and combustion parameters of spark ignition engine fuelled with blends of dimethyl ether and gasoline. It was found that by increasing dimethyl ether content in fuel, fuel consumption could be reduced upto maximum $28 \%$. Also by using a blend of dimethyl ether and gasoline, $\mathrm{HC}$ and $\mathrm{NO}_{\mathrm{x}}$ emissions were reduced. With the blending of dimethyl ether in gasoline, combustion period, flame development and propagation durations were reduced. Also results were obtained that there is an increase in $\mathrm{CO}$ emissions as dimethyl ether content is increased.

M. Mourad and Khaled R. M. Mahmoud et al. [17] investigated performance parameters and emissions of SI engine fueled with propanol blended with gasoline blends. Neat gasoline and blends of 5\%,10\%, 15\% and $20 \%$ of propanol were used. Engine tests were carried out in the speed range of $1000 \mathrm{rpm}$ to $5000 \mathrm{rpm}$.at constant load. The results show that engine torque is increased marginally and brake specific fuel consumption is decreased if the propanol blended gasoline is used. $15 \%$ propanol blend gives best results among all the samples.

Gopinath Dhamodaran et al. [18] studied operating performance, exhaust and combustion characteristics of multi point fuel injection SI engine system fuelled with gasoline blended with di-isopropyl ether. Blending percentage of $10 \%, 20 \%$ and $30 \%$ di-isopropyl ether fuel blend in gasoline was used. The experiments were performed in the speed range of $1400 \mathrm{rpm}-2800 \mathrm{rpm}$ under two different loads. Results of neat gasoline were compared and analyzed with blends of di-isopropyl ether and gasoline. Di-isopropyl ether acts as an oxygenate and provides oxygen for the complete combustion of fuel inside the combustion chamber. Hence, when SI engine was operated with DIPE-gasoline blends, thermal efficiency was enhanced. Also, heat release rate and pressure inside the cylinder was increased. $\mathrm{CO}$ and $\mathrm{HC}$ emissions were reduced considerably by $25 \%$ and $27 \%$ less than neat gasoline whereas $\mathrm{CO}_{2}$ and $\mathrm{NO}_{\mathrm{x}}$ emissions gasoline. It was observed that by adjusting ignition timing, it is possible to reduce $\mathrm{NO}_{\mathrm{x}}$ emissions.

A. Keskin and M. Gürü [19] studied the effect of blending of ethanol and propanol with neat gasoline and using it for SI engine. Exhaust and noise of the engine were parameters under consideration. Blending percentage of $4 \%$ to $20 \%$ with intervals of $4 \%$ on a volume basis were used for ethanol and propanol blending. Carbon monoxide and hydrocarbons emissions were decreased whereas NO emissions increased as the blend percentage increased for ethanol and propanol. Carbon dioxide emissions were increased as the blend percentage increased. Noise levels were comparatively lower with ethanol-gasoline blend. However for propanol-gasoline blend, noise level increased with blend percentage.

Alper Calam et al. [20] studied engine operating performance and exhaust of engine fuelled with gasoline blended with fusel oil. In this study, neat gasoline and fusel oil-gasoline blended samples are investigated for variable ignition timing. Blend percentages of $5 \%$, $10 \%, 15 \%, 20 \%, 30 \%$ and $50 \%$ were used with pure gasoline. It was observed that torque increased whereas fuel consumption reduced with ignition timing. Exhaust gas temperature reduced for all the samples with decrease in ignition timing. Effective efficiency increased with ignition timing for all the samples.

Ahmed N. abdalla et al. [21] studied performance parameters and exhaust emissions of SI engine fuelled with gasoline-fusel oil blend. Fusel oil is a by-product produced from fermented agricultural products. Pure gasoline and gasoline-fusel oil blends of $5 \%, 10 \%, 20 \%$, $30 \%$ and $50 \%$ were used. It was observed that brake power increases for all the blends with speed and it is higher than gasoline for higher speed and $60 \%$ open throttle. Brake specific fuel consumption of $10 \%$ blend was higher than $20 \%$ blend and neat gasoline. $10 \%$ blend 
has shorter combustion period compared to $20 \%$ blend and neat gasoline, hence engine power was observed to be increased. $\mathrm{NO}_{\mathrm{x}}$ emissions were lower for blends as compared to gasoline while $\mathrm{CO}_{2}$ and $\mathrm{HC}$ emissions are increased for blends.

\subsection{Concluding remarks}

From above literature review following remarks can be made:

(1) Alcohols like methanol, ethanol, propanol and butanol reduce emissions of $\mathrm{HC}$ and $\mathrm{CO}$ whereas they increase emissions of $\mathrm{CO}_{2}$ and $\mathrm{NO}_{\mathrm{x}}$ in most of the cases. Also performance parameters like brake thermal efficiency is slightly reduced. Methanol and Ethanol blended with gasoline allows to achieve higher compression ratio without knocking phenomena. blending of ethanol has two important effects on fuel blend properties: An increase in octane rating and decrease in Calorific value. The first effect dominates performance upto $10 \%$ blending and after that second effect starts to dominate. Low reid evaporation pressure of alcohols enables blended gasoline to be stored and transport safely.

(2) Algae oil is not desirable additive as it increases emissions of $\mathrm{NO}_{\mathrm{x}}$ and $\mathrm{CO}$ as compared to neat gasoline. Also, it increases fuel consumption and reduces thermal efficiency.

(3) If acetylene is added to lean mixtures then it increases brake thermal efficiency and reduces $\mathrm{CO}$ emissions. Also, acetylene addition reduces UHC and increases $\mathrm{NO}_{\mathrm{x}}$.

(4) With the blending solketal-gasoline fuel, octane number and brake specific fuel consumption increases. Also, $\mathrm{CO}_{2}$ and $\mathrm{NO}_{\mathrm{x}}$ emissions were hiked with the use of solketal blends as compared to neat gasoline. Hence, solketal can be used to improve octane number.

(5) By addition of dimethyl ether fuel consumption can be reduced marginally. $\mathrm{HC}$ and $\mathrm{NO}_{\mathrm{x}}$ emissions were reduced and $\mathrm{CO}$ emissions were increased. For di-isopropyl ethers-gasoline blends thermal efficiency was improved. $\mathrm{CO}$ and $\mathrm{HC}$ emissions were lowered as compared to neat gasoline whereas $\mathrm{CO}_{2}$ and $\mathrm{NO}_{x}$ emissions were increased for blends as compared to neat gasoline. Ethers are carcinogenic and are responsible for water contamination hence they are banned in several countries to use as an additive.

(6) Fusel oil-gasoline blend increased engine power, $\mathrm{CO}_{2}$ and $\mathrm{HC}$ emissions and $\mathrm{NO}_{\mathrm{x}}$ emissions were reduced as compared to neat gasoline.

\section{Recommendations}

Many things should be taken into consideration before selecting the best alternative fuel or additive for gasoline on a large scale. Researchers have discussed various factors to be considered for additive or alternative fuel selection:
(1) Optimisation in performance and emission parameters for SI engine when operated with additive should be taken into consideration. Performance should not degrade with the use of additive as compared to gasoline. Most likely performance should be enhanced. Emissions should reduce with the use of additives.

(2) Effect of additives on the engine should be determined. Additives should have similar properties as that of gasoline so that modification in the current engines is not required.

(3) Environmental effects should be considered. Additives should not contaminate the environment and should not be harmful for human health. Methyl tert-butyl ether, aromatic alcohols are carcinogenic.

(4) Cost of additive should not exceed that of base fuel. Price of the resultant blend should be affordable,

(5) Availability and accessibility of additive on a large scale should be checked.

(6) Alcohols production on large scale is possible and are widely used today for blending in gasoline. Bio-ethanol is the best option among all the alcohol as it is a renewable fuel.

(7) Other renewable bio-additives are being ignored and not given much importance. Bio-additive like Turmeric leaf oil (Curcuma longa L. oil) should be deeply studied as it is produced from agricultural waste of turmeric leaves.

\section{Economic study for bio-additives}

Usage of ethanol upto $10 \%$ is permitted in India as per national policy but still many petroleum companies are not blending ethanol in gasoline. As petroleum production is not significant in all the countries, many countries are dependent on other nations for their petroleum needs. As the demand is increasing day-by-day due to exponentially increasing population, many developing nations are facing adverse effects on the economy due to heavy imports. If these countries begin to blend bio-additive in gasoline, they can save upto atleast $10 \%$ gasoline and expenditure. Also using bio-additives like ethanol, turmeric leaf oil help to boost the local economy. Use of ethanol in gasoline has increased demand for ethanol hence local sugar factories have got extra income source. As ethanol is produced from waste product in sugar factories, hence production of ethanol has proved beneficial for factories. Use of , turmeric leaf oil in gasoline will ensure extraction of oil from turmeric leaves which is a waste product in the field. By selling turmeric leaves the income of farmers will increase and it will improve the economic condition of farmers.

\section{Conclusions}

Additives can be used in the engine without modification. The emissions using additives can be satisfactorily reduced and performance parameters are 
improved in most of the additives. Bio-additives like ethanol and turmeric leaf oil should be used instead of chemical based additives as they are safer to the environment and efficient in improving performance and reducing emissions. Also bio-additives can be beneficial in improving the local economical conditions.

\section{References}

1. M. Saraswat, N. R. Chauhan, Engg Sci and Tech, an I Journal, 23, 92-100 (2020)

2. M. Mourad, K. Mahmoud, Renewable Energy, 143, 762-771 (2019)

3. A. Elfasakhany, J of Cleaner Production, 139, 1057-1067 (2016)

4. M. Koç, Y. Sekmen, T. Topgul, H. S. Yucesu, Renewable energy, 34, 2101-2106 (2009)

5. A. Elfasakhany, Engg Sci and Tech, an I Journal, 18, 713-719 ( 2015)

6. M. İlhak, S. Tangöz, S. Akansu, N. Kahraman, Energy, 175, 434-444 (2019)

7. Y. Li, J. Gong, Y. Deng, W. Yuan, J. Fu, B. Zhang, App Thermal Engg, 115, 53-63 ( 2017)

8. H. Sharudin, N. Abdullah, G. Najafi, R. Mamat, H. H. Masjuki, App Thermal Engg, 114, 593-600 (2017)

9. I. Gravlos, D. Moshou, Th. Gialamas, P. Xyradakis, D. Kateris, Z. Tsiropoulos, Renewable Energy, 50, 27-32 (2013)

10. E. Alptekin, M. Canakci, App Thermal Engg, 124, 504-509 (2017)

11. Mohsen Ghazikhani, Mohammad Hatami, Behrouz Safari, Davood Domiri Ganji, Prop and Power Research, 2(4), 276-283 (2013)

12. Huseyin Serdar Yucesu, Tolga Topgul, Can Cinar, Melih Okur, App Thermal Engg, 26, 2272-2278

13. Rinu Thomas, M. Sreesankaran, Jeevan Jaidi, Dileep, M. Paul, P. Manjunath, Perspectives in Science, To be published

14. M. Bahattin Celik, Bulent Ozdalyan, Faruk Alkan, Fuel, 90, 1591-1598 (2011)

15. Zhi Tian, Xudong Zhen, Yang Wang, Daming Liu, Xiaoyan Li, Fuel, 259, 1-12 (2020)

16. Changwei Ji, Lei Shi, Shuofeng Wang, Xiaoyu Cong, Teng Su, Menghui Yu, Energy, 126, 335-342 (2017)

17. M. Mourad, Khaled R.M. Mahmoud, Energy, 149, 741-749 (2018)

18. Gopinath Dhamodaran, Ganpathy Sundaram Esakkimuthu, Yashwanth Kutti Pochareddy, Fuel, Article in press

19. A. Keskin and M. Gürü, Energy Sources Part A, 33, 2194-2205 (2011)
20. Alper Calam, Yakup İçingür, Hamit Solmaz, Hasan Yamik, Int J of Green Energy, 12, 767-772 (2015)

21. Ahmed N. Abdalla, Omar I. Awad, Hai Tao, Thamir K. Ibrahim, Rizalman Mamat, Ali Thaeer Hammid, Energy Sources, Part A: Recovery, Utilisation, and environmental effects 